\title{
Odpowiedzialność kierownika jednostki sektora finansów publicznych za naruszenie dyscypliny finansów publicznych
}

\section{Responsibility of the head of the public finance sector for violation of public finance discipline}

\begin{abstract}
Streszczenie:
Kierownik jednostki sektora finansów publicznych pełni szczególną rolę. Jest to podmiot odpowiedzialny za całość gospodarki finansowej jednostki, którą kieruje. Przepisy prawa nakładają na kierownika liczne zadania oraz obowiązki, których niewykonanie lub nienależyte wykonanie wiąże się z poniesieniem przez niego całkowitej odpowiedzialności. W zakresie gospodarki finansowej środkami publicznymi kierownik jednostki jest obowiązany przestrzegać dyscypliny finansów publicznych. Celem niniejszego opracowania jest wskazanie zakresu odpowiedzialności kierownika jednostki sektora finansów publicznych oraz związanych z tym konsekwencji w razie popełnienia czynu naruszającego dyscyplinę finansów publicznych.

Słowa kluczowe: kierownik jednostki sektora finansów publicznych, dyscyplina finansów publicznych

Abstract:

The head of the public finance sector unit has a special role. It is the person responsible for the entire financial management of the unit she/he supervises. Law regulations impose on the head of the unit many tasks and responsibilities. Failure to perform them or their improper performance is connected with complete responsibility. In terms of financial management using public means, the head of the unit is obliged to observe the discipline of public finances. The aim of this study is to indicate the scope
\end{abstract}


Martyna Lizak - Odpowiedzialność kierownika jednostki...

of responsibility of the head of the public finance sector unit and related consequences in the event of an act that violates the public finance discipline.

Keywords: head of the public finance sector unit; discipline of public finances

\section{Wprowadzenie}

Uregulowania prawne dotyczące dyscypliny finansów publicznych chronią dwie najistotniejsze zasady funkcjonowania sektora finansów publicznych. Pierwsza zasada dotyczy racjonalnego i efektywnego gospodarowania środkami publicznymi oraz majątkiem publicznym. Drugą zasadę można ująć jako ścisłe przestrzeganie procedur oraz zakresu uprawnień do rozporządzania środkami publicznymi¹. Głównym aktem prawnym określającym zasady oraz zakres odpowiedzialności za naruszenie dyscypliny finansów publicznych jest ustawa z dnia 17 grudnia 2004 r. o odpowiedzialności za naruszenie dyscypliny finansów publicznych².

W literaturze przedmiotu oraz ustawodawstwie brak normatywnej definicji pojęcia dyscypliny finansów publicznych. Niemniej jednak pojęcie to dotyczy przede wszystkim ustalania, poboru i egzekucji należności stanowiących środki publiczne oraz gospodarowania nimi przez odpowiednie podmioty ${ }^{3}$. Z kolei odpowiedzialność za naruszenie dyscypliny finansów publicznych można rozumieć jako:

(...) ponoszenie przewidzianych wskazaną ustawą ujemnych konsekwencji za zdarzenia lub stany rzeczy podlegające ujemnej kwalifikacji normatywnej przez podmioty wskazane w tej ustawie 4 . s. 679.

${ }^{1}$ E. Malinowska-Misiąg, W. Misiąg, Finanse publiczne w Polsce, Warszawa 2007,

2 Ustawa z dnia 17 grudnia 2004 r. o odpowiedzialności za naruszenie dyscypliny finansów publicznych (t.j. Dz.U. z 2019 r., poz. 2020), dalej: u.o.n.d.f.p.

${ }^{3}$ M. Wróblewska, Dyscyplina finansów publicznych, [w:] A. Drwiłło, D. Maśniak (red.), Leksykon prawa finansowego. 100 podstawowych pojęć, Warszawa 2015, s. 103.

${ }_{4}^{4}$ P. Pomorski, Odpowiedzialność za naruszenie dyscypliny finansów publicznych, [w:] P. Smoleń (red.), Prawo finansów publicznych. Kompendium Akademickie, Warszawa 2012, s. 145. 
Instytucja odpowiedzialności za naruszenie dyscypliny finansów publicznych winna powodować przede wszystkim wyeliminowanie naruszeń prawa, usunięcie skutków jego nieprzestrzegania, przywrócenie stanu respektowania prawa, a w razie spowodowania strat czy też innych szkód - ich zrekompensowanie. Wobec tego w literaturze przedmiotu podkreśla się trojaką funkcję odpowiedzialności za naruszenie dyscypliny finansów publicznych: prewencyjną, represyjną oraz kompensacyjną

Kierownik jednostki sektora finansów publicznych to osoba, która jest najczęściej pociągana do odpowiedzialności dyscyplinarnej. Przede wszystkim dotyczy to sytuacji, gdy kierownik zostanie obwiniony o naruszenie dyscypliny finansów publicznych w konsekwencji popełnienia przez niego czynu, który jest naruszeniem takiej dyscypliny. W niektórych przypadkach może zostać również pociągnięty do odpowiedzialności w wyniku czynu popełnionego przez pracownika jednostki, którą kieruje. Należy zaznaczyć, iż dyscyplina finansów publicznych ma na celu pociąganie do odpowiedzialności osób, które łamią fundamentalne zasady gospodarki finansowej ${ }^{6}$. Zgodnie $\mathrm{z}$ art. 53 ust. 1 ustawy z dnia 27 sierpnia 2009 r. o finansach publicznych ${ }^{7}$ to właśnie kierownik jest odpowiedzialny za całość gospodarki finansowej jednostki sektora finansów publicznych.

Odpowiedzialność w sferze prawa finansowego dąży przede wszystkim do zapewnienia prawidłowego stosowania prawa. Nie chodzi tutaj wyłącznie o regulacje prawa finansowego, lecz również o wszelkie inne przepisy prawa związane z działalnością finansową oraz ze statusem prawnym danej jednostki organizacyjnej. Co więcej, ma zapewnić przestrzeganie statutów tych jednostek oraz ustaleń

5 I. Czaja-Hliniak, Odpowiedzialność prawnofinansowa na przykładzie odpowiedzialności za naruszenie dyscypliny finansów publicznych, „Studia Prawnicze: rozprawy i materiały" 2009, t. 5, s. 118.

${ }^{6}$ K. Puchacz, Nowe zasady odpowiedzialności za naruszenie dyscypliny finansów publicznych. Praktyczny komentarz do zmian w ustawie., Gdańsk 2012, s. 13.

7 Ustawa z dnia 27 sierpnia 2009 r. o finansach publicznych (t.j. Dz.U. z 2019 r., poz. 2020), dalej: u.f.p. 
Martyna Lizak - Odpowiedzialność kierownika jednostki...

zawieranych przez nie umów. Dlatego też duże znaczenie odgrywa poprawność wydawanych przez kierownika jednostki sektora finansów publicznych decyzji oraz jego rola w zakresie gospodarowania środkami publicznymi ${ }^{8}$.

Niniejszy artykuł ma na celu analizę przypadków, w których kierownik jednostki sektora finansów publicznych może zostać pociągnięty do odpowiedzialności za naruszenie dyscypliny finansów publicznych. Ponadto celem artykułu jest ukazanie dyscypliny finansów publicznych jako narzędzia prawnego, stanowiącego w polskim systemie prawnym szczególny instrument przedmiotu ochrony finansów publicznych o charakterze represyjnym. Dlatego podjęto również analizę prawnych konsekwencji czynów powodujących naruszenie dyscypliny finansów publicznych, w tym sankcji przewidzianych w u.o.n.d.f.p.

\section{Pojęcie kierownika jednostki sektora finansów publicznych}

Zarówno u.f.p. jak i u.o.n.d.f.p. nie formułują legalnej definicji kierownika jednostki. Jednak możemy ją odnaleźć w ustawie z dnia 29 września 1994 r. o rachunkowości ${ }^{9}$, która podaje taką definicję na potrzeby wykładni swoich przepisów.

Zgodnie z art. 3 ust. 1 pkt 6 u.r. przez kierownika jednostki rozumie się:

Członka zarządu lub innego organu zarządzającego, a jeżeli organ jest wieloosobowy - członków tego organu, z wyłączeniem pełnomocników ustanowionych przez jednostkę. W przypadku spółki jawnej i spółki cywilnej za kierownika jednostki uważa się wspólników prowadzących sprawy spółki, w przypadku spółki partnerskiej - wspólników prowadzących sprawy spółki albo zarząd, a w odniesieniu do spółki komandytowej i spółki komandytowo-akcyjnej - komplementariuszy prowadzących sprawy spółki. W przypadku osoby fizycznej prowadzącej działalność gospodarczą za kierownika jednostki uważa

\footnotetext{
${ }^{8}$ I. Czaja-Hliniak, Odpowiedzialność prawnofinansowa na przykładzie..., op. cit., s. 118.

9 Ustawa z dnia 29 września 1994 r. o rachunkowości (t.j. Dz.U. z 2019 r., poz. 1680), dalej: u.r.
} 
się tę osobę; do osób wykonujących wolne zawody przepis ten stosuje się odpowiednio. Za kierownika jednostki uważa się również likwidatora, a także syndyka lub zarządcę ustanowionego $\mathrm{w}$ postępowaniu restrukturyzacyjnym oraz zarządcę sukcesyjnego, o którym mowa w ustawie z dnia 5 lipca 2018 r. o zarządzie sukcesyjnym przedsiębiorstwem osoby fizycznej, albo osobę, o której mowa w art. 14 tej ustawy, która dokonała zgłoszenia, o którym mowa w art. 12 ust. 1c ustawy z dnia 13 października 1995 r. o zasadach ewidencji i identyfikacji podatników i płatników.

W literaturze przedmiotu przyjmuje się, iż kierownik jednostki to osoba, która posiada kompetencje nie tylko do podejmowania decyzji w zakresie bieżącego funkcjonowania jednostki, lecz również jest uprawniona do działania w imieniu kierowanej jednostki, a w szczególności do reprezentowania jej na zewnątrz ${ }^{10}$.

Przez pojęcie „kierownik” w języku polskim rozumie się osobę zarządzającą czymś, jakimś działem, zespołem ludzi. Z kolei wyrażenie „kierować” oznacza rządzić czymś, kimś, stać na czele czegoś czy też wytyczać drogi działania. Kierownikiem jest więc osoba, która kieruje, zarządza działem danej instytucji bądź jakiegoś przedsiębiorstwa, a poza tym należy do kierownictwa organizacji, instytucji. Biorąc pod uwagę przepisy prawa, kierownik jednostki sektora finansów publicznych jest określany również jako „dyrektor”, „dyrektor generalny”, „szef”, „prezes”, „wójt”, „,burmistrz” lub „prezydentem miasta”11.

Zatem do kierowników jednostki jako podmiotów podlegających odpowiedzialności za naruszenie dyscypliny finansów publicznych zalicza się: wójta, burmistrza, prezydenta miasta - jako kierownika urzędu gminy (miasta); przewodniczącego zarządu powiatu oraz województwa (czyli odpowiednio - starostę powiatu i marszałka województwa) - jako kierownika starostwa i urzędu marszałkowskiego; kierowników jednostek budżetowych (np. dyrektor domu dziecka) i samorządowych zakładów budżetowych (np. dyrektor zarządu nieru-

$10 \mathrm{~W}$. Miemiec, Zakres podmiotowy odpowiedzialności za naruszenie dyscypliny finansów publicznych, [w:] R. Mastalski, E. Fojcik-Mastalska (red.), Prawo finansowe, Warszawa 2013, s. 122.

${ }^{11}$ L. Lipiec-Warzecha, Odpowiedzialność za naruszenie dyscypliny finansów publicznych. Komentarz, Warszawa 2012, s. 58. 
Martyna Lizak - Odpowiedzialność kierownika jednostki...

chomości komunalnych); kierowników samorządowych osób prawnych zaliczanych do sektora finansów publicznych (np. dyrektor Narodowego Centrum Kultury). Są to głównie podmioty, które pełnią kierownicze funkcje w jednostkach samorządu terytorialnego ${ }^{12}$.

\section{Obowiązki kierownika jednostki sektora finansów publicznych}

Do odpowiedzialności za naruszenie dyscypliny finansów publicznych zgodnie $\mathrm{z}$ art. 4 ust. 1 pkt 2 u.o.n.d.f.p. może być pociągnięty kierownik jednostki sektora finansów publicznych. Zgodnie z przepisami prawa materialnego do zadań kierownika jednostki należy wykonywanie obowiązków obejmujących, jak już wcześniej wspomniano, całość gospodarki finansowej tej jednostki - na podstawie art. 53 u.f.p. Zakres jego obowiązków jest zatem bardzo szeroki. Kierownik odpowiada nie tylko za organizację całej gospodarki finansowej w jednostce, lecz także za kierowanie wykonywaniem określonych zadań finansowych oraz kontrolowanie i czuwanie nad przestrzeganiem dyscypliny finansów publicznych ${ }^{13}$.

Kierownik jednostki jest odpowiedzialny również stosownie do art. 69 ust. 1 pkt 2 oraz art. 282 u.f.p. za zapewnienie funkcjonowania adekwatnej, skutecznej i efektywnej kontroli zarządczej, a także zapewnienie warunków niezbędnych do niezależnego, obiektywnego i efektywnego prowadzenia audytu wewnętrznego ${ }^{14}$.

Z kolei jeśli chodzi o inne akty prawne, to należy odnieść się do u.r., która zgodnie $\mathrm{z}$ art. 4 ust. 5 obliguje kierownika do prowadzenia ra-

12 J. M. Salachna, R. Trykozko, Odpowiedzialność za gospodarkę finansowa j.s.t. oraz $z$ tytułu dyscypliny finansowej, [w:] C. Kosikowski, J. M. Salachna, Finanse samorzq̨dowe. 580 pytań i odpowiedzi: wzory uchwał, deklaracji, decyzji, umów, Warszawa 2012, s. 797.

${ }^{13}$ A. Rotter, Zakres podmiotowy odpowiedzialności za naruszenie dyscypliny finansów publicznych z tytułu nieprawidłowości $w$ dysponowaniu środkami publicznymi, [w:] A. Talik, W. Robaczyński, A. Babczuk (red.), Dyscyplina finansów publicznych. Podstawy i zakres odpowiedzialności, Warszawa 2015, s. 28.

14 I. Motowilczuk, Dyscyplina finansów publicznych po zmianach, Warszawa 2012, s. 13. 
chunkowości jednostki. Należy również wskazać na ustawę z dnia 29 stycznia 2004 r. - Prawo zamówień publicznych ${ }^{15}$. Stosownie do art. 18 ust. 1 u.p.z.p. kierownik jednostki odpowiada za przygotowanie oraz przeprowadzanie postępowań o udzielenie zamówień publicznych. Ponadto ważnym aktem prawnym regulującym obowiązki kierownika jednostki jest Rozporządzenie Ministra Rozwoju i Finansów z dnia 9 stycznia 2018 r. w sprawie sprawozdawczości budżetowej ${ }^{16}$. Zgodnie z par. 4 oraz par. 9 ust. 1 kierownik jest obowiązany do sporządzania i przekazywania sprawozdań w imieniu jednostki, które muszą być rzetelne i prawidłowe pod względem merytorycznym oraz formalnorachunkowym ${ }^{17}$.

Uzgodnienie, w jakim zakresie odpowiedzialność za naruszenie dyscypliny finansów publicznych ponosi kierownik jednostki sektora finansów publicznych, musi odnosić się do ustroju każdej konkretnej jednostki. Status kierownika jednostki sektora finansów publicznych może być określony w przepisach o charakterze powszechnie obowiązującym oraz bezpośrednio w przepisach regulujących działalność danej jednostki. Zakres zadań i obowiązków kierownika może być wskazany również w aktach prawa wewnętrznego (m.in. w statutach, regulaminach organizacyjnych), a także w aktach indywidualnych (np. $\mathrm{w}$ umowie o pracę) ${ }^{18}$.

\section{Zakres odpowiedzialności kierownika jednostki sektora finansów publicznych}

Odpowiedzialność kierownika jednostki finansów publicznych związana z prawem do dysponowania środkami publicznymi jest ponoszona za działania szkodliwe dla funkcjonowania finansów pu-

\footnotetext{
15 Ustawa z dnia 29 stycznia 2004 r. - Prawo zamówień publicznych (t.j. Dz.U. z 2019 r., poz. 1843), dalej: u.p.z.p.

16 Rozporządzenie Ministra Rozwoju i Finansów z dnia 9 stycznia 2018 r. w sprawie sprawozdawczości budżetowej (Dz.U. z 2018 r., poz. 109).

17 I. Motowilczuk, Dyscyplina finansów publicznych..., op. cit., s. 13.

18 L. Lipiec-Warzecha, Odpowiedzialność za naruszenie..., op. cit., s. 58.
} 
Martyna Lizak - Odpowiedzialność kierownika jednostki...

blicznych oraz stanowi naruszenie norm prawnych sprecyzowanych w u.o.n.d.f.p.

Najogólniej mówiąc, czyny naruszające dyscyplinę finansów publicznych mają związek z pobieraniem środków publicznych, wydatkowaniem środków publicznych, zaciąganiem zobowiązań, przeprowadzaniem inwentaryzacji, a także ze sporządzaniem sprawozdania budżetowego ${ }^{19}$.

Katalog czynności naruszających dyscyplinę finansów publicznych jest wskazany w art. 5-18 u.o.n.d.f.p. Czyny te można podzielić na kilka grup. Pierwszą grupę czynów stanowią działania przyczyniające się do zmniejszenia środków należnych Skarbowi Państwa, j.s.t. bądź innym jednostkom sektora finansów publicznych. Zgodnie z art. 5 ust. 1 u.o.n.d.f.p. działania te dotyczą przede wszystkim nieustalenia, niepobrania, nieprzekazania do właściwego budżetu lub niezgodnego z prawem umorzenia należności. Do drugiej grupy czynów naruszających dyscyplinę finansów publicznych zalicza się działania związane z niewłaściwym dysponowaniem środkami publicznymi. Przykładem takiego czynu, stosownie do art. 11 ust. 1 u.o.n.d.f.p. jest:

(...) dokonanie wydatku ze środków publicznych bez upoważnienia określonego ustawą budżetową, uchwałą budżetową lub planem finansowym albo z przekroczeniem zakresu tego upoważnienia lub z naruszeniem przepisów dotyczących dokonywania poszczególnych rodzajów wydatków.

W zakresie trzeciej grupy czynów można wyróżnić inne działania mające związek z nieprawidłową gospodarką finansową jednostek. Do tej grupy można zaliczyć naruszenie przepisów o audycie wewnętrznym, naruszenie przepisów o umowie koncesji czy też naruszenie obowiązków sprawozdawczych związanych z inwentaryzacją. Czynem naruszającym dyscyplinę finansów publicznych jest także niezgodne z prawem dokonywanie zmian w planie finansowym bądź budżecie ${ }^{20}$.

${ }^{19}$ E. Malinowska-Misiąg,W. Misiąg, Finanse publiczne..., op. cit., s. 683.

${ }^{20}$ K. Wojewoda-Buraczyńska, Naruszenie dyscypliny finansów publicznych, [w:] W. Wójtowicz (red.), Zarys finansów publicznych i prawa finansowego, Warszawa 2017, s. 498-499. 
Katalog naruszeń dyscypliny finansów publicznych obejmuje również sferę zamówień publicznych. Do czynów naruszających dyscyplinę w tym obszarze można zaliczyć m.in. zawarcie umowy $\mathrm{w}$ trybie niezgodnym z przepisami o zamówieniach publicznych, zawarcie umowy w sposób zakłócający konkurencję, zawarcie umowy w sprawie zamówienia publicznego bez zachowania formy pisemnej, na czas dłuższy niż określony bądź nieoznaczony, z wyłączeniem przypadków określonych w przepisach dotyczących zamówień publicznych czy też przed ogłoszeniem orzeczenia przez Krajową Izbę Odwoławczą, z naruszeniem przepisów o zamówieniach publicznych ${ }^{21}$.

Należy więc stwierdzić, iż naruszenie dyscypliny finansów publicznych może polegać na bezprawnym działaniu (np. przekazanie lub udzielenie dotacji z naruszeniem zasad lub trybu przekazywania lub udzielania dotacji) lub zaniechaniu działania nakazanego przez prawo (np. niedokonanie w terminie zwrotu dotacji w należnej wysokości). Katalog naruszeń zawarty w art. 5-18 u.o.n.d.f.p. należy rozważać razem z innymi ustawami oraz aktami wykonawczymi wydanymi na ich podstawie, mając na uwadze, iż zgodnie z art. 25 u.o.n.d.f.p. przedmiotowa odpowiedzialność jest niezależna od odpowiedzialności sprecyzowanej w innych przepisach prawnych, a w zetknięciu z odpowiedzialnością karną bądź karną skarbową - w razie prawomocnego skazania - postępowanie o naruszenie dyscypliny finansów publicznych podlega umorzeniu ${ }^{22}$.

Zgodnie $\mathrm{z}$ art. 4 ust. 1 pkt 3 u.o.n.d.f.p. odpowiedzialności za naruszenie dyscypliny finansów publicznych podlegają również:

(...) pracownicy jednostek sektora finansów publicznych lub inne osoby, którym odrębną ustawą lub na jej podstawie powierzono wykonywanie obo-

${ }^{21}$ E. Kornberger-Sokołowska, Budżet państwa, [w:] M. Bitner et al., Prawo finansowe. Prawo finansów publicznych. Prawo podatkowe. Prawo bankowe, Warszawa 2017, s. 172.

22 P. Litwiniuk, Odpowiedzialność z tytułu naruszenia dyscypliny finansów publicznych, [w:] M. Podstawka (red.), Finanse. Instytucje, instrumenty, podmioty, rynki, regulacje, Warszawa 2017, s. 928. 
Martyna Lizak - Odpowiedzialność kierownika jednostki...

wiązków w takiej jednostce, których niewykonanie lub nienależyte wykonanie stanowi czyn naruszający dyscyplinę finansów publicznych.

Powyższy przepis koresponduje z jedną z zasad gospodarki finansowej jednostki sektora finansów publicznych sprecyzowanej w art. 53 ust. 2 u.f.p., stosownie do którego:

Kierownik jednostki może powierzyć określone obowiązki w zakresie gospodarki finansowej pracownikom jednostki. Przyjęcie obowiązków przez te osoby powinno być potwierdzone dokumentem w formie odrębnego imiennego upoważnienia albo wskazania w regulaminie organizacyjnym tej jednostki.

Odpowiedzialność ta może się więc tyczyć tylko i wyłącznie kierownika jednostki lub pracownika jednostki, którego obowiązki wiążą się z wykonywaniem zadań w zakresie gospodarki finansowej jednostki, a także zarówno pracownika, jak i kierownika jednostki23.

Powierzenie obowiązków pracownikom może mieć charakter indywidualny, gdzie ważny jest podmiotowy zakres upoważnienia, a obowiązki zostają przypisane konkretnemu pracownikowi bądź charakter generalny poprzez wskazanie obowiązków każdego pracownika w regulaminie organizacyjnym danej jednostki. W tym ostatnim przypadku pracownik nie dokonuje odrębnej czynności o przyjęciu powierzonych mu obowiązków ${ }^{24}$.

Przywołany wyżej art. 53 ust. 2 u.f.p. wymaga precyzyjnego oraz niepozostawiającego żadnych wątpliwości wyliczenia powierzanych obowiązków. Z orzecznictwa GKO wynika, iż wyraźne powierzenie i przyjęcie przez danego pracownika obowiązków jest podstawą do pociągnięcia osoby do odpowiedzialności na podstawie u.o.n.d.f.p. W nawiązaniu do tej reguły należy przytoczyć tezę orzeczenia GKO

${ }^{23}$ C. Kosikowski, Podmioty odpowiedzialne za naruszenie dyscypliny finansów publicznych, [w:] C. Kosikowski, E. Ruśkowski (red.), Finanse publiczne i prawo finansowe, Warszawa 2006, s. 865.

${ }^{24}$ W. Bożek, Działalność orzecznicza Głównej Komisji Orzekającej w sprawach o naruszenie dyscypliny finansów publicznych: analiza głównych kierunków w dorobku orzeczniczym w latach 2010-2015, Szczecin 2016, s. 75. 
z dnia 28 lutego 2013 r. ${ }^{25}$, podkreślającą istotę powierzenia obowiązków pracownikowi:

Powierzenie obowiązków w zakresie gospodarki finansowej ma na celu uświadomienie pracownikowi, że za ewentualne nieprawidłowości w zakresie mu powierzonym, będzie on ponosił odpowiedzialność za naruszenie dyscypliny finansów publicznych tak jakby był kierownikiem tej jednostki. Kierownik bowiem jest odpowiedzialny za całość gospodarki finansowej tej jednostki zgodnie art. 53 ust. 1 u.f.p. 26 .

Mając powyższe na uwadze, warto przywołać również orzeczenie GKO z dnia 16 stycznia 2006 r. ${ }^{27}$, w którym wskazano, iż u.o.n.d.f.p. jest aktem szczególnym, ponieważ ma na celu ochronę budżetu przed nieodpowiednimi i sprzecznymi z prawem działaniami jednostek sektora finansów publicznych z jednoosobowym kierownictwem na czele, charakteryzującym się jednoosobową decyzyjnością. Ponadto: „tylko w wyraźnie scedowanych i przyjętych przez pracowników sprawach mogą być oni ukarani na mocy u.o.n.d.f.p.". Niniejsza ustawa wprowadza zatem swoiste domniemanie odpowiedzialności za naruszenie dyscypliny finansów publicznych przez kierownika jednostki sektora finansów publicznych. Zgodnie z orzecznictwem RKO w Poznaniu $\mathrm{z}$ dnia 12 sierpnia $2011 \mathrm{r}^{28}$ :

(...) obalenie tego domniemania może nastąpić przez wykazanie, że kierownik jednostki powierzył w sposób precyzyjny i niepozostawiający wątpliwości wskazanemu imiennie pracownikowi obowiązki, których nieprawidłowe wykonanie stanowi naruszenie dyscypliny finansów publicznych ${ }^{29}$.

Można więc stwierdzić, iż odpowiedzialność kierownika jednostki sektora finansów publicznych za funkcjonowanie gospodarki finan-

25 Orzeczenie GKO z dnia 28 lutego 2013 r., BDF1/4900/113/111/12/3432, http://www.mf.gov.pl. 76.

${ }^{26}$ W. Bożek, Działalność orzecznicza Głównej Komisji Orzekającej..., op. cit., s. 75-

27 Orzeczenie GKO z dnia 16 stycznia 2006 r., DF/GKO/Odw.-77/101-102/2005/ 649, http://www.mf.gov.pl.

28 Orzeczenie RKO w Poznaniu z dnia 12 sierpnia 2011 r., DB-0965/94/98/11, http://www.cirf.gov.pl.

${ }^{29}$ A. Rotter, Zakres podmiotowy odpowiedzialności..., op. cit., s. 29. 
Martyna Lizak - Odpowiedzialność kierownika jednostki...

sowej jednostki, którą zarządza, jest niezbywalna. Norma wyrażona w przepisie art. 53 ust. 1 u.f.p. ustanawia ogólną kompetencję kierownika jednostki do wykonywania wszelkich czynności w zakresie gospodarki finansowej. Należy uznać, iż pojęcie odpowiedzialności tyczy się zarówno uprawnienia, jak i obowiązku kierownika do wykonywania wszystkich czynności w ramach prowadzenia gospodarki finansowej jednostki. Stwierdzenie to potwierdza art. 53 ust. 2 u.f.p., z którego można wywnioskować, że w razie braku przekazania pracownikom jednostki określonych, wyraźnie sprecyzowanych obowiązków w zakresie gospodarki finansowej, to $w$ dalszym ciągu spoczywają one na kierowniku. Normę ogólna zawartą w art. 53 ust. 1 u.f.p. uzupełnia norma zawarta w przepisie art. 53 ust. 5 u.f.p., która stanowi, iż:

(...) w przypadku jednostek obsługiwanych przez jednostki obsługujące, odpowiedzialność za całość gospodarki finansowej jednostki obsługiwanej ponosi nie kierownik tej jednostki, ale kierownik jednostki obsługującej ${ }^{30}$.

\section{Kontrola zarządcza $w$ jednostkach sektora finansów publicznych}

Zgodnie z definicją zawartą w art. 68 u.f.p. kontrola zarządcza to ogół działań podejmowanych w celu realizacji określonych zadań w sposób zgodny z prawem, efektywny, oszczędny i terminowy. Kontrolę zarządczą należy rozumieć w kontekście ogólnie rozumianych procesów zarządzania jednostką. Najistotniejszym elementem kontroli zarządczej jest system wyznaczania zadań i celów oraz rutynowe sprawdzanie stopnia ich realizacji. Kontrola ta ma charakter kompleksowy. Jej celem jest przede wszystkim zapewnienie efektywności i skuteczności działania, zgodności działalności z procedurami wewnętrznymi i przepisami prawa, ochrony zasobów, wiarygodności sprawo-

30 M. Bitner, Komentarz do art. 53 ustawy o finansach publicznych, [w:] W. Misiąg (red.), Ustawa o finansach publicznych. Ustawa o odpowiedzialności za naruszenie dyscypliny finansów publicznych. Komentarz, Warszawa 2017, s. 215. 
zdań czy też przestrzegania i promowania zasad etycznego postępowania ${ }^{31}$.

Elementem kontroli zarządczej jest niewątpliwie kontrola finansowa. Kierownik jednostki sektora finansów publicznych jest zobowiązany do efektywnego oraz skutecznego zarządzania daną jednostką. Jest on odpowiedzialny za zapewnienie systemu kontroli oraz zadbanie, by czynności w obrębie szeroko rozumianej gospodarki finansowej były realizowane wyłącznie przez upoważnione do tego osoby. Z tego względu jeżeli czynności w zakresie gospodarki finansowej bądź zamówień publicznych naruszające dyscyplinę finansów publicznych będą realizowane przez osobę nieupoważnioną, odpowiedzialność za naruszenie dyscypliny finansów publicznych poniesie kierownik jednostki w przypadku, gdy zaniedbał kontrolę zarządczą bądź nie wykonywał obowiązków w tym zakresie i miało to bezpośredni wpływ na naruszenie dyscypliny finansów publicznych. Nie ulega wątpliwości, iż dopuszczenie do podejmowania działań władczych w ramach gospodarowania środkami publicznymi bądź mieniem przez nieupoważnione do tego osoby oznacza niewykonywanie obowiązków w zakresie kontroli zarządczej. Organizacja pracy jest jednym z fundamentalnych elementów zarządzania, a brak sprecyzowania przez kierownika, kto i za co odpowiada, jest tego inherentnym przejawem ${ }^{32}$.

Naruszenia dyscypliny finansów publicznych w zakresie kontroli zarządczej są określone w art. 18c. u.o.n.d.f.p. Kierownik jednostki sektora finansów publicznych może zostać pociągnięty do odpowiedzialności w przypadku niewykonania lub nienależytego wykonania publicznych określonych obowiązków, jeżeli miały one wpływ na:

- uszczuplenie wpływów należnych tej jednostce, Skarbowi Państwa lub jednostce samorządu terytorialnego;

31 M. Wróblewska, Dyscyplina finansów..., op. cit., s. 687.

32 A. Kościńska-Paszkowska, Odpowiedzialność za naruszenie dyscypliny finansów publicznych, [w:] K. Borowska, A. Kościńska-Paszowska, T. Bolek, Odpowiedzialność za naruszenie dyscypliny finansów publicznych. Komentarz, Warszawa 2012, s. 27-28. 
Martyna Lizak - Odpowiedzialność kierownika jednostki...

- dokonanie wydatku powodującego przekroczenie kwoty wydatków ustalonej w planie finansowym jednostki;

- zaciągnięcie zobowiązania bez upoważnienia określonego ustawą budżetową, uchwałą budżetową lub planem finansowym albo z przekroczeniem zakresu tego upoważnienia lub z naruszeniem przepisów dotyczących zaciągania zobowiązań przez jednostkę sektora finansów publicznych;

- niewykonanie $\mathrm{w}$ terminie zobowiązania jednostki, w tym obowiązku zwrotu należności celnej, podatku, nadpłaty lub nienależnie opłaconych składek na ubezpieczenie społeczne lub zdrowotne;

- udzielenie zamówienia publicznego wykonawcy, który nie został wybrany w trybie określonym w przepisach o zamówieniach publicznych;

- zawarcie umowy ramowej bez przeprowadzenia postępowania w trybie określonym w przepisach o zamówieniach publicznych;

- zawarcie umowy w sprawie zamówienia publicznego lub umowy ramowej z naruszeniem przepisów o zamówieniach publicznych dotyczących formy pisemnej umowy, okresu, na który umowa może być zawarta, lub w przypadku wniesienia odwołania, terminu jej zawarcia;

- niewyłączenie z postępowania o udzielenie zamówienia publicznego osoby podlegającej wyłączeniu z takiego postępowania na podstawie przepisów o zamówieniach publicznych;

- unieważnienie postępowania o udzielenie zamówienia publicznego z naruszeniem przepisów o zamówieniach publicznych określających przesłanki unieważnienia tego postępowania;

- zawarcie umowy koncesji na roboty budowlane lub usługi z koncesjonariuszem, który nie został wybrany zgodnie z przepisami o umowie koncesji na roboty budowlane lub usługi;

- zawarcie umowy koncesji na roboty budowlane lub usługi z naruszeniem przepisów o umowie koncesji na roboty budowlane lub usługi dotyczących formy pisemnej umowy, okresu, na który umo- 
wa może być zawarta lub w przypadku wniesienia odwołania na czynność wyboru najkorzystniejszej oferty - terminu jej zawarcia;

- unieważnienie postępowania o zawarcie umowy koncesji na roboty budowlane lub usługi z naruszeniem przepisów o umowie koncesji na roboty budowlane lub usługi;

- dokonanie, w zakresie gospodarki finansowej lub w postępowaniu o udzielenie zamówienia publicznego lub przygotowaniu tego postępowania albo w postępowaniu o zawarcie umowy koncesji na roboty budowlane lub usługi, czynności naruszającej dyscyplinę finansów publicznych przez osobę nieupoważnioną do wykonania tej czynności;

- działanie lub zaniechanie skutkujące zapłatą ze środków publicznych kary, grzywny lub opłaty stanowiącej sankcję finansową, do których stosuje się przepisy o postępowaniu egzekucyjnym w administracji.

Naruszeniem dyscypliny finansów publicznych w zakresie kontroli zarządczej jest więc zachowanie kierownika jednostki mające wpływ na zaistnienie wskazanych $\mathrm{w}$ art. 18c u.o.n.d.f.p. nieprawidłowości. Zgodnie ze słownikiem języka polskiego przez pojęcie „wpływ” rozumie się oddziaływanie na kogoś lub na coś bądź też skutek tego oddziaływania, natomiast słowo „wpływanie” oznacza wywarcie nacisku, wpływu na kogoś lub na coś czy też oddziaływanie. Wobec tego w celu udowodnienia naruszenia dyscypliny finansów publicznych w zakresie kontroli zarządczej nie jest konieczne wskazanie dowodów potwierdzających niewykonanie lub nienależyte wykonanie przez kierownika jednostki sektora finansów publicznych obowiązków, a wystarczające jest ukazanie wpływu tego zachowania na zaistnienie $w$ jednostce okoliczności sprecyzowanych $w$ art. 18c u.o.n.d.f.p. ${ }^{33}$

33 W. Bożek, Niewykonanie lub nienależyte wykonanie przez kierownika jednostki sektora finansów publicznych obowiq̨zków w zakresie kontroli zarządczej w jednostce sektora finansów publicznych, „Zeszyty Naukowe Uniwersytetu Szczecińskiego. Finanse, Rynki Finansowe, Ubezpieczenia" 2014, nr 65, s. 40. 
Martyna Lizak - Odpowiedzialność kierownika jednostki...

\section{Sankcje za naruszenie dyscypliny finansów publicznych}

Zgodnie $\mathrm{z}$ art. 31 u.o.n.d.f.p. karami za naruszenie dyscypliny finansów publicznych są: upomnienie, nagana, kara pieniężna oraz zakaz pełnienia funkcji związanych $\mathrm{z}$ dysponowaniem środkami publicznymi.

Kary zostały wymienione w sposób progresywny. Najłagodniejszą z nich jest upomnienie, które ma charakter niepieniężny i nie skutkuje dalszymi konsekwencjami dla osoby sankcjonowanej. Kara upomnienia jest swoistym napomnieniem, ostrzeżeniem, którego celem jest przede wszystkim zapobieżenie naruszaniu przez obwinionego dyscypliny finansów publicznych w przyszłości ${ }^{34}$. Wymierzana jest przede wszystkim w przypadku, gdy stopień szkodliwości naruszenia dyscypliny finansów publicznych nie jest znaczny 35 .

Kara nagany ma również charakter niemajątkowy. Jest ona surowsza w stosunku do kary upomnienia. Zgodnie z art. 32 u.o.n.d.f.p. kara nagany poza skutkami wynikającymi z ukarania pociąga za sobą ujemną lub negatywną ocenę kwalifikacyjną, która przewidziana jest w przepisach szczególnych ${ }^{36}$. Takiej ocenie podlegają przykładowo pracownicy samorządowi, pracownicy NIK czy też pracownicy Służby Cywilnej. Jednokrotna ujemna bądź negatywna ocena kwalifikacyjna nie wywołuje szczególnych konsekwencji dla ukaranego, natomiast powtórna taka ocena wiąże się najczęściej z rozwiązaniem stosunku pracy lub odwołaniem z zajmowanego stanowiska ${ }^{37}$.

Należy zaznaczyć, iż kary niepieniężne niekiedy mogą powodować negatywne skutki finansowe. Niektóre instytucje w swych uregulowaniach wewnętrznych mają zapisy, iż pracownicy ukarani za naruszenie dyscypliny finansów publicznych nie mogą otrzymać np. premii.

Trzecią sankcją pod względem dolegliwości jest kara pieniężna. Jako środek dyscyplinujący i sankcjonujący nie ma charakteru odszkodowawczego, ponieważ płatna jest bezpośrednio do budżetu państwa

\footnotetext{
34 P. Litwiniuk, Odpowiedzialność z tytułu naruszenia..., op. cit., s. 929.

35 E. Chojna-Duch, Prawo finansowe. Finanse publiczne., Warszawa 2017, s. 200.

36 M. Wróblewska, Dyscyplina finansów..., op. cit., s. 680.

37 P. Pomorski, Odpowiedzialność za..., op. cit., s. 147.
} 
i stanowi jego dochód. Podobnie jak orzeczenie kary nagany wymierzenie kary pieniężnej wywołuje ujemne dla sprawcy skutki wynikające z negatywnej oceny kwalifikacyjnej, określone w odrębnych przepisach. Zgodnie $\mathrm{z}$ art. 31 ust. 2 oraz 3 u.o.n.d.f.p.:

Karę pieniężną wymierza się w wysokości od 0,25 do trzykrotności miesięcznego wynagrodzenia osoby odpowiedzialnej za naruszenie dyscypliny finansów publicznych - obliczonego jak wynagrodzenie za czas urlopu wypoczynkowego - należnego w roku, w którym doszło do tego naruszenia. Jeżeli nie jest możliwe ustalenie wysokości tego wynagrodzenia, karę pieniężną wymierza się w wysokości od 0,25 do pięciokrotności przeciętnego wynagrodzenia ${ }^{38}$.

Najdotkliwszą sankcją wymierzaną za naruszenie dyscypliny finansów publicznych jest zakaz pełnienia funkcji związanych z dysponowaniem środkami publicznymi. Powyższą karę wymierza się na okres od roku do 5 lat. Zastosowanie sankcji zakazu pełnienia funkcji związanych $\mathrm{z}$ dysponowaniem środkami publicznymi wiąże się $\mathrm{z}$ wykluczeniem na czas określony w orzeczeniu o ukaraniu możliwości pełnienia przez sprawcę w jednostce sektora finansów publicznych funkcji kierownika ${ }^{39}$.

\section{Podsumowanie}

Reasumując, można stwierdzić, iż obowiązkiem kierownika jednostki sektora finansów publicznych jest przede wszystkim przestrzeganie ładu w gospodarce finansowej. Rola kierownika jednostki wiąże się zatem z ogromną odpowiedzialnością. Wszelkie niedopilnowanie bądź nienależyte wykonanie przez niego zadań i obowiązków wskazanych w aktach prawnych zarówno powszechnie, jak i wewnętrznie obowiązujących może być związane z poniesieniem przez niego określonych konsekwencji.

Kierownik to osoba, która powinna wiedzieć, jak prawidłowo zarządzać jednostką, jak odpowiednio sprawować kontrolę nad pracow-

\footnotetext{
38 P. Litwiniuk, Odpowiedzialność z tytułu naruszenia..., op. cit., s. 930.

39 Ibidem.
} 
Martyna Lizak - Odpowiedzialność kierownika jednostki...

nikami, aby dane przedsiębiorstwo czy też instytucja funkcjonowała zgodnie z prawem. To osoba, która powinna posiadać odpowiednie umiejętności zarządcze oraz powinna mieć świadomość ciężaru ponoszonej odpowiedzialności.

Z dorobku orzecznictwa GKO wynika pewien wzorzec kierownika jednostki sektora finansów publicznych oraz cechy, którymi powinien się charakteryzować. Są to przede wszystkim odpowiednie wykształcenie, doświadczenie, kwalifikacje zawodowe oraz indywidualne umiejętności, predyspozycje, które pozwalają na gromadzenie i wydatkowanie środków publicznych, jak i gospodarowanie mieniem w imieniu kierowanej przez niego jednostki sektora finansów publicznych w sposób zgodny z prawem, oszczędny, celowy, a także z poszanowaniem zasady uzyskania jak najlepszych wyników z poczynionych nakładów ${ }^{40}$.

W orzeczeniu GKO z dnia 13 stycznia 2011 r. ${ }^{41}$ wskazano, że:

Każda osoba podejmująca się pełnienia funkcji kierowniczej w jednostce sektora finansów publicznych powinna mieć wiedzę z zakresu finansów publicznych, znać przepisy obowiązujące w zakresie przyjmowanych obowiązków jak również mieć świadomość odpowiedzialności za ich nieprzestrzeganie. Rozpatrując jednak kwestię odpowiedzialności za popełnienie czynów karalnych, nie można abstrahować od sytuacji panującej wewnątrz jednostki i w jej otoczeniu zewnętrznym wpływając ewentualnie na możliwości działania kierownika jednostki.

Można zatem stwierdzić, iż standardy względem kierowników jednostek sektora finansów publicznych ulegają podwyższeniu, ponieważ są oni zobowiązani do zwiększonej staranności oraz znajomości i przestrzegania przepisów z zakresu finansów publicznych, co jest powiązane z profesjonalnym charakterem wykonywanej przez nich działalności zawodowej. Kierownicy powinni posiadać zarówno wiedzę merytoryczną z zakresu działalności danej jednostki, jak i powinni wykazywać się w takim samym stopniu wiedzą organizacyjną. Prowadzi to do przyjęcia domniemania, iż kierownik jednostki sektora finansów publicz-

40 W. Bożek, Działalność orzecznicza Głównej Komisji Orzekającej..., op. cit., s. 77.

41 Orzeczenie GKO z dnia 13 stycznia 2011 r., BDF1/4900/109/119/10/3244, http://www.mf.gov.pl. 
nych zna przepisy powszechnie obowiązującego prawa, a poza tym potrafi zachować się w sposób im odpowiadający ${ }^{42}$.

Wobec tego kierownik jednostki sektora finansów publicznych od początku pełnienia tej funkcji powinien przestrzegać zasad dyscypliny finansów publicznych oraz mieć świadomość konsekwencji swoich czynów. Jako podmiot odpowiedzialny za całość gospodarki finansowej danej jednostki zobligowany jest stać na straży przestrzegania przepisów prawych w tej jednostce, a ponadto poprzez prawidłową kontrolę zarządczą postępować w sposób zapewniający jej prawidłowe funkcjonowanie.

\section{Bibliografia:}

Bitner M., Chojna-Duch E., Chowaniec J., Grzybowski M., Karwat P., Kornberger-Sokołowska E., Lachowicz M., Litwińczuk H., Modzelewski W., Radzikowski K., Supera-Markowska M., Ślifirczyk M., Tetłak K., Waluga M., Prawo finansowe. Prawo finansów publicznych. Prawo podatkowe. Prawo bankowe, Wyd. Wolters Kluwer, Warszawa 2017.

Borowska K., Kościńska-Paszowska A., Bolek T., Odpowiedzialność za naruszenie dyscypliny finansów publicznych. Komentarz, Wyd. LexisNexis, Warszawa 2012.

Bożek W., Działalność orzecznicza Głównej Komisji Orzekającej w sprawach o naruszenie dyscypliny finansów publicznych: analiza głównych kierunków w dorobku orzeczniczym w latach 2010-2015, Wyd. Uniwersytet Szczeciński, Szczecin 2016.

Bożek W., Niewykonanie lub nienależyte wykonanie przez kierownika jednostki sektora finansów publicznych obowiązków w zakresie kontroli zarządczej w jednostce sektora finansów publicznych, „Zeszyty Naukowe Uniwersytetu Szczecińskiego. Finanse, Rynki Finansowe, Ubezpieczenia” 2014, nr 65.

Chojna-Duch E., Prawo finansowe. Finanse publiczne, Wyd. Oficyna Prawa Polskiego, Warszawa 2017.

Czaja-Hliniak I., Odpowiedzialność prawnofinansowa na przykładzie odpowiedzialności za naruszenie dyscypliny finansów publicznych, „Studia Prawnicze: rozprawy i materiały" 2009, t. 5, ss. 117-133.

42 W. Bożek, Działalność orzecznicza Głównej Komisji Orzekającej..., op. cit., s. 78. 
Martyna Lizak - Odpowiedzialność kierownika jednostki...

Drwiłło A. (red.), Podstawy finansów i prawa finansowego, Wyd. Wolters Kluwer, Warszawa 2018.

Drwiłło A., Maśniak D. (red.), Leksykon prawa finansowego. 100 podstawowych pojęć, Wyd. C.H. Beck, Warszawa 2015.

Kosikowski C., Ruśkowski E. (red.), Finanse publiczne i prawo finansowe, Wyd. Dom Wydawniczy ABC, Warszawa 2006.

Kosikowski C., Salachna J.M., Finanse samorzq̨dowe. 580 pytań i odpowiedzi: wzory uchwał, deklaracji, decyzji, umów, Wyd. Wolters Kluwer, Warszawa 2012.

Lipiec-Warzecha L., Odpowiedzialność za naruszenie dyscypliny finansów publicznych. Komentarz, Wyd. Wolters Kluwer, Warszawa 2012.

Malinowska-Misiąg E., Misiąg W., Finanse publiczne w Polsce, Wyd. Lexis Nexis, Warszawa 2007.

Mastalski R., Fojcik-Mastalska E. (red.), Prawo finansowe, Wyd. Wolters Kluwer, Warszawa 2013.

Misiąg W. (red.), Ustawa o finansach publicznych. Ustawa o odpowiedzialności za naruszenie dyscypliny finansów publicznych. Komentarz, Wyd. C. H. Beck, Warszawa 2017.

Motowilczuk I., Dyscyplina finansów publicznych po zmianach, Wyd. Infor Ekspert, Warszawa 2012.

Orzeczenie GKO z dnia 13 stycznia 2011 r., BDF1/4900/109/119/10/3244.

Orzeczenie GKO z dnia 16 stycznia 2006 r., DF/GKO/Odw.-77/101-102/ $2005 / 649$.

Orzeczenie GKO z dnia 28 lutego 2013 r., BDF1/4900/113/111/12/3432.

Orzeczenie RKO w Poznaniu z dnia 12 sierpnia 2011 r., DB-0965/94/98/11.

Podstawka M. (red.), Finanse. Instytucje, instrumenty, podmioty, rynki, regulacje., Wyd. Naukowe PWN SA, Warszawa 2017.

Puchacz K., Nowe zasady odpowiedzialności za naruszenie dyscypliny finansów publicznych. Praktyczny komentarz do zmian w ustawie., Ośrodek Doradztwa i Doskonalenia Kadr Sp. z o.o., Gdańsk 2012.

Rozporządzenie Ministra Rozwoju i Finansów z dnia 9 stycznia 2018 r. w sprawie sprawozdawczości budżetowej (Dz.U. z 2018 r., poz. 109).

Smoleń P. (red.), Prawo finansów publicznych. Kompendium Akademickie, Wyd. Wolters Kluwer, Warszawa 2012.

Talik A., Robaczyński W., Babczuk A. (red.), Dyscyplina finansów publicznych. Podstawy i zakres odpowiedzialności, Wyd. C. H. Beck, Warszawa 2015. 
Ustawa z dnia 17 grudnia 2004 r. o odpowiedzialności za naruszenie dyscypliny finansów publicznych (t.j. Dz.U. z 2019 r., poz. 2020).

Ustawa z dnia 27 sierpnia 2009 r. o finansach publicznych (t.j. Dz.U. z 2019 r., poz. 2020).

Ustawa z dnia 29 stycznia 2004 r. - Prawo zamówień publicznych (t.j. Dz.U. z 2019 r., poz. 1843).

Ustawa z dnia 29 września 1994 r. o rachunkowości (t.j. Dz.U. z 2019 r., poz. 1680).

Wójtowicz W. (red. nauk.), Zarys finansów publicznych i prawa finansowego, Wolters Kluwer, Warszawa 2017. 